
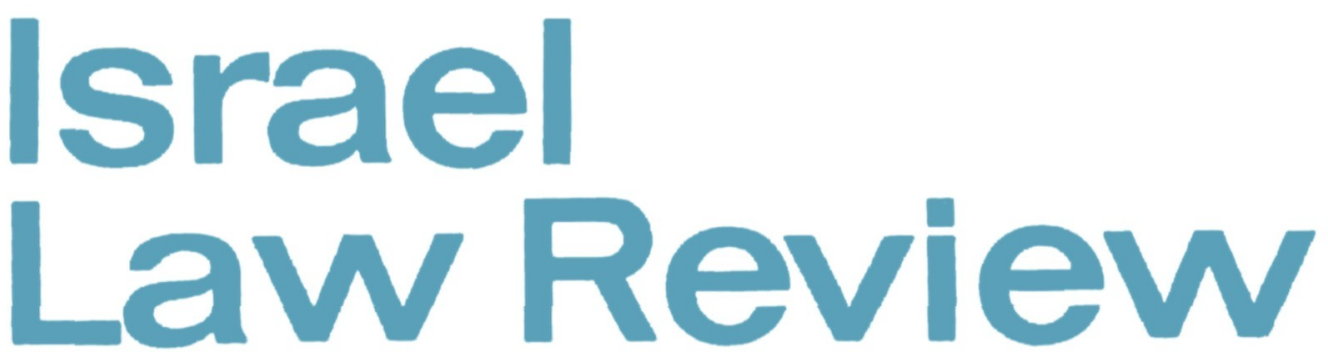

\title{
ARIICLES
}

G. Tedeschi 513 On Tort Liability for "Wrongful Life"

Eliahu Harnon 539 Res Judicata and Identity of Actions

A. M. Apelbom 562 Common Law à l'americaine

L. C. Green 580 An International Lawyer Looks at Comparative Law

J. J. Lador-Lederer 593 The International Corporation-Its Status in International Law

Ralph A. Newman 616 The Principles of Equity as a Source of World Law

\section{LEGAL EDUCATION}

Yoram Dinstein 632 Legal Aid to Developing Countries

\section{REPORT OF COMMITTEE}

636 Report on Questions of Traffic and Work Accidents

\section{CASES}

M. D. Gouldman

662 The Headmaster as Local Councillor

Leah D. Landau

665 Vacant (State) Lands and the Rights of the Cultivator

\section{BOOKS}

A. Witkon 669 Dr. A. Lapidoth, Evasion and Avoidance of Income Tax

S. G. 673 Gideon Hausner, Justice in Jerusalem 
EDITORIAL BOARD

B. Akzin S. Ginossar A. V. Levontin

EXECUTIVE EDITOR EDITORIAL ASSOCIATE
A. M. Apelbom
P. Elman

Unless otherwise indicated, translations of Israel Laws quoted in articles are taken from the Authorized Translation of the Ministry of Justice and translations from law reports in Hebrew are made by the authors.
(C) 1966

For glossary and abbreviations see p. 3 of the cover.

Printed in Israel at the Jerusalem Post Press, Jerusalem

נדפס בדפוס ג'רוסלם פוסט, ירושלים 


\section{Israel Law Review}

is published by the Israel Law Review Association four times a year, ca. 150 pages per Number.

\section{Annual Subscription Rates-}

Israel

U.K. \& Europe

U.S.A. \& other countries
IL 22

\& 3 ) or the

$\$ 10$ equivalent

(post free)

\section{ORDER FORM}

To: The Israel Law Review Association

c/o Faculty of Law

Hebrew University

Jerusalem, Israel.

Please enter my (our) subscription to the ISRAEL LAW REVIEW for .... year(s), beginning

Volume 1, $1966 \square \quad$ Volume 2, 1967

Please renew my (our) subscription for volume 2

Payment enclosed

Please bill me

Name

Address

Date

Signature

(please print in block letters) 


\section{PUBLICATIONS AVAILABLE AT THE FACULTY OF LAW}

The Hebrew University, Jerusalem, Israel.

Scripta Hieroslymitana-Publications of The Hebrew University of Jerusalem.

Edited by B. Akzin, volume V, Studies in Law, 1958, $\$ 4.50$.

Edited by G. Tedeschi and U. Yadin, volume XVI, Studies in Israel Legislative Problems, 1966, \$6.

Henry E. Baker-The Legal System of Israel, 1961, $21 \mathrm{~s}$.

Y. Z. Blum-Historic Titles in International Law, 1965, \$11.50.

Y. Dinstein-The Defence of "Obedience to Superior Orders" in International Law, 1965, £3.

Doris Lankin-Biennial Survey of Israel Law 1962-1963, published under the auspices of the Institute for Legislative Research and Comparative Law, 1964, \$2.

A. V. Levontin-The Myth of International Security, 1957, \$4.

Ernst Livneh-Israel Legal Bibliography in European Languages, published under the auspices of the Institute for Legislative Research and Comparative Law, 1963, \$2.

N. Feinberg and J. Stoyanovsky-The Jewish Yearbook of International Law 1948, 1949, \$8.

N. Feinberg-The Legality of a "State of War" after the Cessation of Hostilities, 1961, \$1.

Amnon Rubinstein-Jurisdiction and Illegality, 1965, 45s.

G. Tedeschi-Studies in Israel Law, 1960, \$3.

G. Tedeschi-Studies in Israel Private Law, 1966, \$10.

R. Yaron-Gifts in Contemplation of Death in Jewish and Roman Law, 1960, 35s.

R. Yaron-Law of the Aramaic Papyri, 1961, 30s.

I. Zamir-The Declaratory Judgment, 1962, £ 2 15s.

Edited by I. Drapkin, Proceedings of the 12th International Course in Criminology-The Causation and Prevention of Crime in Developing Countries, 1963, \$6. 


\title{
THE LIONEL COHEN LECTURES
}

\author{
Published by the Magnes Press \\ The Hebrew University, \\ Jerusalem, Israel.
}

(Distributed in Great Britain, the Commonwealth and Europe by the Oxford University Press.)

Prof. A. L. Goodhart, The Spirit of the English Law, 1953, \$0.50.

Sir Raymond Evershed, Aspects of English Equity, 1954, \$0.50.

Lord Cohen of Walmer, One Hundred Years of Limited Liability Companies in England, 1957, \$0.75.

Sir David Hughes Parry, The Changing Conception of Contracts in English Law, 1958, (out of print).

Lord Parker of Waddington, The History and Development of Commercial Arbitration and Recent Development in the Supervisory Powers of the Courts over Inferior Tribunals, 1959, \$1.

Prof. O. Kahn-Freund, The Growth of Internationalism in English Private International Law, 1960, \$1.25.

Lord Denning, Responsibility Before The Law, 1961, (out of print).

Lord McNair, The Expansion of International Law, 1962, \$1.

Sir Seymour E. Karminski, Some Aspects of the Development of English Personal Law in the Last Century, 1963, \$1.

Prof. H. L. Hart, The Morality of the Criminal Law, 1964, \$1.

Prof. Glanville L. Williams, The Mental Element in Crime, 1965, $\$ 1.50$.

Mr. M. C. Setalvad, The Role of English Law in India, 1966, \$2. 


\title{
ISRAELI REPORTS TO THE SEVENTH CONGRESS OF COMPARATIVE LAW
}

\author{
Edited by \\ U. YADIN

\section{Contents}

G. Tedeschi: The Sanction for Breach of Contract, Including Anticipatory Breach. Augusto Levi: From One-man Company to Commercial Foundation.

Z. Sher: The Protection of Notorious Marks.

Z. Sher: The Protection of Cinematographic Films.

R. Lapidoth: Les conflicts de la loi nationale avec les traités internationaux. Leon Blum: The Parliamentary Control over the Administration including the Ombudsman.

Ernst Livneh: Legal Restrictions on the Freedom of Religion and Expression. Ariel Hecht: Legal Restrictions on the Freedom of Occupation.

M. D. Gouldman: The "Right of Return" and the Problem of the Fugitive Offender.

Judith Pelley-Karp: Judicial Limits of Administrative Discretion.

A. Lapidoth: Tax Measures Designed to Encourage Investment.

S. Z. Feller: Compétence des jurisdictions pénales Israéliennes pour les infraction commises à l'étranger.

\section{Supplement}

S. Ginossar: La société d'une seule personne.

1966. $155+4$ pages.

$$
\text { IL6.-, \$2.-. }
$$

\section{LEGAL ASPECTS OF TOWN PLANNING IN ISRAEL}

\section{By \\ M. D. GOULDMAN}

1. Introductory.

Contents

2. Planning at the Local Level.

3. The Control of Development.

4. Positive Planning.

5. Planning and the Expropriation of Land.

6. Compensation and Betterment.

7. Parks, Open Spaces and Appearance.

8. Government Building and the Enforcement of Planning Law.

9. Conclusions.

English translation of The Planning and Building Law, 5725-1965.

1966. 187 pages.

IL6.-, \$2. -

Both books are published by and available through:

The Institute for Legislative Research and Comparative Law

Faculty of Law

Hebrew University

Jerusalem, Israel. 
EARLIER ROYAL SOCIETY OF ARTS AWARD CITATION

"Professor Stone is a great jurist by virtue of his own creative and critical thinking, and his book is worthy of the epithet of greatness."

Stone, LEGAL SYSTEM AND LAWYERS' REASONINGS $(1964,415+$ xxiv pp., price $\$ 8.40)$.

Stone, HUMAN LAW AND HUMAN JUSTICE

(1965, $415+$ xxiv pp., price $\$ 8.00)$.

Stone, SOCIAL DIMENSIONS OF LAW AND JUSTICE $(1966,933+\operatorname{xxxv}$ pp., price $\$ 13.50)$.

EARLY REVIEWS OF THE SUCCESSOR BOOKS

“... the fruits of a most profound and careful scholarship and an immense erudition. In a sense it would be valuable if only as a log of the course of one impressive mind across the ocean of writing about justice... the attractiveness of this book will lie in the sheer thoroughness of its scholarship on one hand, and in the author's personal conclusions on the present state of Justice theory on the other... Professor Stone's additions to and improvements in the traditional canon are legion..." (D. L. Perrott, in (1965) 8 J. of Public Teachers of Law, 322-24.) “. . packed with arguments ... in fuli command of a very wide range of materials ... so well-organised that the central issues of justice remain always in focus'. (Associate Professor Paul Diesing, in (1965) 15 13ufialo $\mathbf{L}$. R., 244-49). "... contrives to handle enormous learning with a deft skill which constantly shows the problem of justice in a different light, irradiating familiar problems anew and giving them a continual freshness of interest... The handling of historical material in this book keeps one's sense of wonder constantly alive ... " (Professor Colin Howard, in (1966) 44 Texas L.R. 822-25.)

. a significant contribution towards the development of a better understanding of the concept of justice and, perhaps, through this understanding, an improved system of laws ..." (Vincent F. Kilborn in (1965) Alabama L.R. 224-27.)

"In 1946, Julius Stone. . . flnished a great work entitled The Province and Fanction of Jaw. Further development of the ideas and materials in that book is now leading to the publication of 'three major works in the next year or so... We are in for some wonderful reading ... Nobody has ever made such an analysis (of common law judicial techniques in new factual situations) with the fulness of Professor Stone... Stone has no close competitor among those who are writing about the entire range of legal theory..." (D. Rose, in (1965) 40 Tulane L. R. 219-224.) The expositions are obviously erudite and exhaustive within their recognized limits ..." (E.A.R. in (1965) Review of Metaphysics 384-85.)

“.. persistent probing frequently illuminated by subtle insight and sensitivity $\therefore$ In an era of minute philosophers (Stone) has written jurisprudence in the "grand manner". (Professor Jerome Hall in (1966) George Washington L.R. 389-90.) “. . clarifles the process of man's intellectual impulses emerging from funded experience... impels the realisation that the way of true reform is not to ignore the past but to encompass it ..." (Justice S. H. Hofstadter, in N.Y. L.J., Jan. 14 . 1966.)

"No reviewer can convey adequately the impact which this work has on the reader. This work and its companion volumes should rank as one of the outstanding contributions to legal thought of this century." (Professor B. J. George, in (1965) 13 Kansas L.R. 465-68.)

“... well-balanced, lucidly and temperately presented.... does not run away from any of the problems, but tackles them with earnest resolution . . . admirably scholarly ... with excellent indices . . compulsory reading for all who desire to penetrate in any depth the muddied waters of analytical jurisprudence. The two remaining volumes will be awaited with great . . . anticipation." (Professor Dennis Lloyd, in (1965) 81 Iaw Q. Rev. 599-602.)

"It is not the good fortune of many to have written a classic in 1946 , . . f frequently consulted and cited, and now almost two decades later to produce a comprehensive trilogy... (which gives) promise that the complete work will long stand as a major achievement". (Lester E. Denonn, in American Bar A.J., May 1965.)

To: Maitland Publications Pty. Ltd., 11th Floor, 65 York Street, Sydney, Australia:

Please find remittance for $\$ 24$ (Australian) (or $\$ 26.40$ (U.S.) in payment for Stone's three works on Legal System and Lawyers' Reasonings, Human Law and Human Justice, and Social Dimensions of Law and Justice (reduced $20 \%$, post free).

Date Signed

Address Phone

Single Books at List Price

Send your order to the Publishers, Maitland Publications Pty. Ltd. as above. 


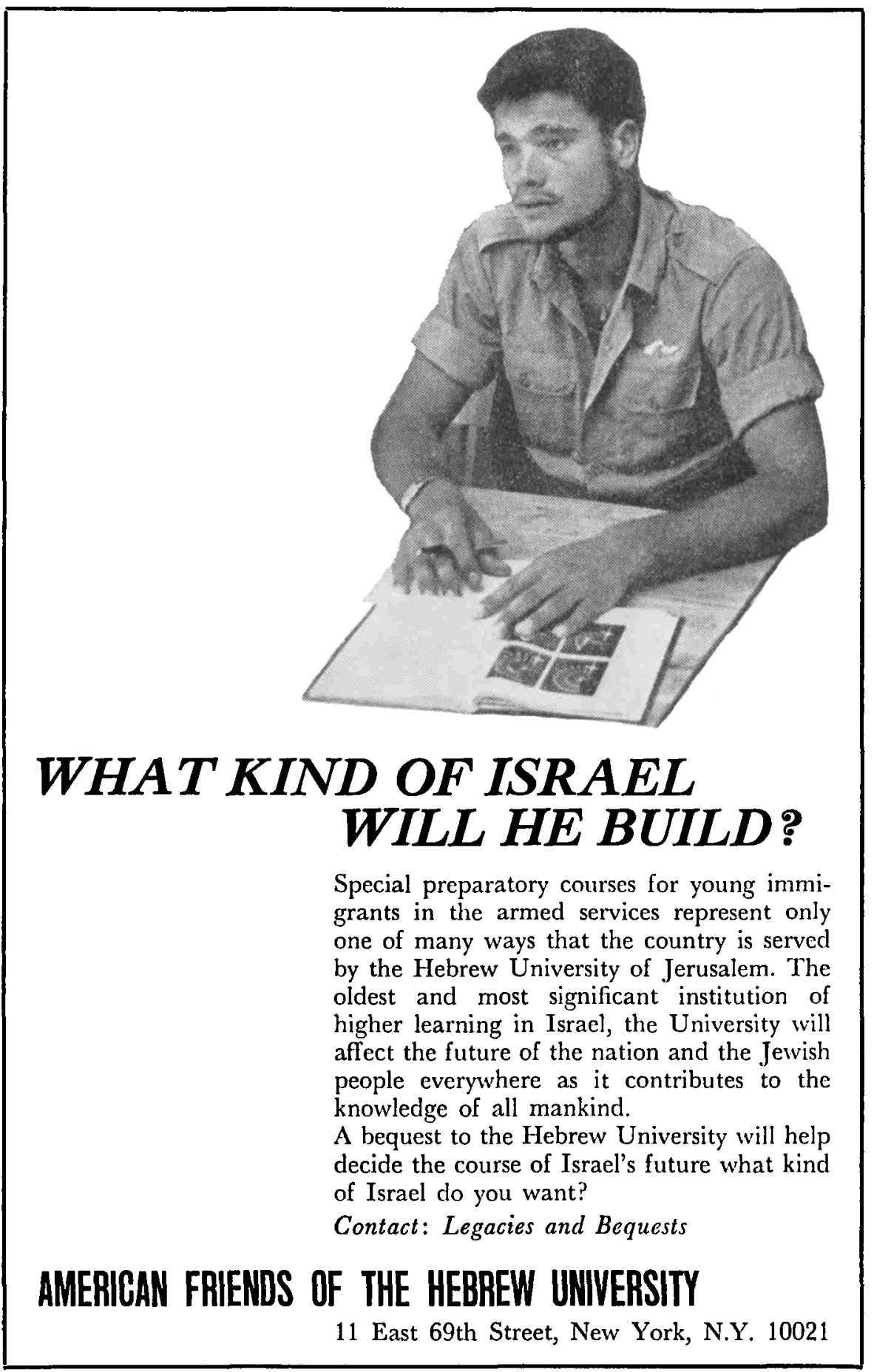

